\title{
GENOTOXIC AND CARCINOGENIC STUDIES OF NORGESTREL IN DROSOPHILA MELANOGASTER
}

\author{
AHMED ABOU-EISHA*, ADEL E EI-DIN \\ Department of Cell Biology, National Research Centre, 33 El-Bohouth St., Dokki, Giza, P.0. Box 12622, Egypt. \\ Email: aaboueisha@hotmail.com
}

Received: 18 May 2018, Revised and Accepted: 25 June 2018

\section{ABSTRACT}

Objective: The aim of this study was to investigate, for the first time, the possible in vivo genotoxic and carcinogenic activity associated with exposure to norgestrel (NGT) drug through employing the very recently established and adjusted genotoxic and tumorigenic methods in Drosophila melanogaster.

Methods: Two in vivo genotoxic test systems were used; one detects the somatic mutation and recombination effects (somatic mutation and recombination test [SMART] wing-spot test) and the other detects the primary DNA damage (the comet test) in the body cells of $D$. melanogaster. On the other hand, the warts (wts)-based SMART assay is a vital genetic examination in Drosophila used to identify and characterize cancer potential of compounds.

Results: Four experimental doses of NGT were used (ranging from $0.24 \mu \mathrm{M}$ to $16 \mu \mathrm{M}$ ). NGT was found to be non-genotoxic at all tested concentrations even at the highest dose level $16 \mu \mathrm{M}$ and failed to increase the frequency of tumors in the somatic cells of $D$. melanogaster.

Conclusion: Our results strengthen the hypothesis that steroidal drugs might act through a non-genotoxic carcinogen mechanism where the carcinogenic properties occur by direct stimulation of cellular proliferation through a steroid receptor-mediated mechanism. In addition, the results obtained in this research work may contribute to highlighting the importance of NGT as a potent neuroprotective antioxidant drug.

Keywords: Norgestrel, Wing-spot assay, Comet assay, Warts-based somatic mutation and recombination test.

(C) 2018 The Authors. Published by Innovare Academic Sciences Pvt Ltd. This is an open access article under the CC BY license (http://creativecommons. org/licenses/by/4. 0/) DOI: http://dx.doi.org/10.22159/ajpcr.2018.v11i10.27374

\section{INTRODUCTION}

Norgestrel (NGT) is a synthetic progestin drug that is widely used as an oral contraceptive drug alone or in combination with synthetic estrogen to deal with several cases of hormonal disturbances in women $[1,2]$. In recent times, several clinical studies have revealed that NGT is a powerful neuroprotective antioxidant agent, successfully protect photoreceptor cells from morphological changes associated with exposure to high levels of reactive oxygen species [3,4]. In addition, this hormonal drug maintains retinal function through increasing the expression of basic fibroblast growth factor that has been shown to be protective in different experimental models of neurodegeneration [3-5].

Like all the synthetic progestins, this drug spreads throughout the cell membrane forming complexes with nuclear receptors within the cytoplasm, which pass through nuclear pores and initiate gene expression $[1,6]$. Nevertheless, several medical studies have indicated that long-term exposure to synthetic progestins/oral contraceptives increases the likelihood of occurrence of various types of cancer in humans [7]. In addition, treatment with progestins leads to reduce the latency of a breast tumor and increases tumor growth $[8,9]$.

It has been demonstrated that various types of synthetic progestins, such as chlormadinone acetate, medroxyprogesterone acetate, and norethynodrel have a DNA damaging property, as evidenced by chromosomal damage and induction of SCEs $[7,10,11]$. However, the available data regarding the mutagenicity of NGT are inconclusive because both positive and negative results have been reported $[6,12]$. Furthermore, the authors $[12,13]$ found that the positive genotoxic effects of NGT are only produced in the presence of a metabolic activation system, and the reactive metabolites of it might be in command of its genotoxicity. In the same domain, metabolic activation of steroidal drugs produces reactive oxygen species, which can alter the DNA structure resulting in mutations and induces cancer $[12,14]$.

Drosophila was selected in this inquiry because it is seen as a good in vivo model system for testing genetic toxicology. In this context, the role of Drosophila is time-efficient, allowing a rapid genotoxic analysis, when compared to rodents. Moreover, it has a metabolic system fit for activation of mutagenic and carcinogenic agents similar to the liver in mammals [15]. Further, fruit flies develop overgrown tissue that looks very similar to a human tumor when certain genes are mutated. Unlike tissue culture work, the fly tumor can be induced in the context of intact epithelia, which is comparable to human tumors [16]. Furthermore, in light of the fact that Drosophila has no nuclear progesterone receptor [17], so the NGT drug cannot produce an effect through the cellular proliferation pathway.

The aim of this study was to investigate, for the first time, the possible in vivo genotoxic and carcinogenic activity associated with NGT exposure by employing the very recently established and adjusted genotoxic and tumorigenic methods in Drosophila melanogaster. On the one hand, we used two methods in this work to detect the genotoxic effect; one detects the somatic mutation and recombination effects (somatic mutation and recombination test [SMART] wing-spot test), whereas the other detects the primary DNA damage (the comet test). On the other hand, to determine if the changes induced in DNA by this drug were not only recombinogenic but also an enhancer of tumor growth, we used warts (wts)-based SMART assay. This method is a vital genetic examination in Drosophila used to identify and characterize cancer potential of compounds [18]. Since this synthetic progestin is used on a large scale, thus there is a requirement to add more information on its mutagenic activity and its possible dangers to human health. 


\section{METHODS}

\section{Chemicals and dose selection}

NGT (CAS No.6533-00-2) was purchased from (Cayman Chemical Company, MI, USA) with purity $\geq 95 \%$. It was dissolved in dimethyl sulfoxide (DMSO) (DMSO, CAS No. 67-68-5, Hi-Media Pvt. Limited, Mumbai, India), which acts as a negative control at a final concentration $0.2 \%$ in Drosophila food according to Nazir et al. 2003 [19]. The control larvae received normal Drosophila food. Mitomycin C (MMC, CAS No. 50-07-7), was purchased from Kyowa Hakko. Co. Ltd. (Tokyo, Japan) used as positive control, was dissolved in double-distilled water to the concentration used, just before the treatment. The concentration of MMC used in this experiment was based on studies of the mitotic recombination in D. melanogaster (third instar larvae), induced by MMC [20]. Phenylthiourea (PTU, CAS 103-85-5, $\geq 95 \%$ purity) were obtained from Sigma-Aldrich (USA); N-lauroylsarcosine sodium hydroxide and Triton X-100 were from Fluka Chemical AG (Buchs, Switzerland); low melting point agarose (LMA), normal melting-point agarose (NMA), sodium hydroxide, and sodium chloride were from Carl Roth $\mathrm{GmbH}$ (Karlsruhe, Germany); the $\mathrm{Ca}^{2+}$ and $\mathrm{Mg}^{2+}$ free phosphatebuffered saline (PBS), Tris buffer, and 4/,6- Diamidine-2-phenylindole (DAPI) were from HiMedia Laboratories Pvt., Ltd., (Mumbai, India).

The concentrations of NGT tested in the present study ranged from $0.24 \mu \mathrm{M}$ to $16 \mu \mathrm{M}$. All concentrations lie within the scope of clinical doses in humans with the exception of the highest dose, which corresponded to 10 -fold the maximal therapeutic dose of NGT. NGT was dissolved in DMSO at $0.2 \%$ final concentration. DMSO was used as a negative control, while MMC $50 \mu \mathrm{M}$ was used as a positive control.

\section{Drosophila strains}

The following $D$. melanogaster strains were used in this study: The multiple wing-hair strain $m w h$, the flare-3 strain with a genetic structure $f l r^{3} / T M 3$, the wild-type (Oregon $\mathrm{R}+$ ), and wts ( $w t s / T M 3, S b^{1}$ ). The first two strains were used for the wing-SMART assay. According to the comet assay, we used the wild-type (Oregon $\mathrm{R}+$ ). The strain $w t s / T M 3, S b^{1}$ was used for the wts-based SMART assay, which carries one lethal allele wts on chromosome 3 , balanced by a TM3 chromosome, having multiple inversions, characterized by dominant stubble $(S b)$ mutation, phenotypically identified by the short bristles [21]. The flies and larvae in all experiments were cultured at $25 \pm 1^{\circ} \mathrm{C}$ with $60 \%$ humidity on standard Drosophila food containing agar, cornmeal, sugar, and yeast as described by Dhanraj et al. 2017 [22].

\section{Wing-spot test}

Virgin females of the flr 3 strain were mated to $m w h$ males as previously described by Marcos and Carmona 2013 [23]. Eggs from this cross were collected during $8 \mathrm{~h}$ periods in culture bottles containing the standard Drosophila food. The third instar larvae from this cross were placed in glass flasks containing standard Drosophila food and treated with different concentrations of NGT. The larvae were fed on this medium until pupation. All experiments were performed at $25 \pm 1^{\circ} \mathrm{C}$ and at approximately $60 \%$ of relative humidity. The emerged flies were collected from the treatment vials and stored in $70 \%$ ethanol. Afterward, their wings were carefully removed, mounted in Faure's solution on microscope slides and inspected, under $\times 400$ magnifications, for the presence of small single spots, large single spots, and twin spots according to the method of Graf et al. 1984 [24]. In each series, we examined 80 wings (40 individuals). The scoring of flies and data evaluation were conducted following the standard procedures for the wing spot assay, as used in the investigation of Demir et al. 2010 [25].

\section{Comet assay}

Third-instar larvae (72 \pm 4 -h-old) were transferred to standard Drosophila food containing different concentrations of NGT, ranging from $0.24 \mu \mathrm{M}$ to $16 \mu \mathrm{M}$. Larvae were fed on this medium during $24 \pm 2 \mathrm{~h}$. All the experiments were performed at $25 \pm 1^{\circ} \mathrm{C}$ and at $\sim 60 \%$ relative humidity. D. melanogaster hemocytes were collected according to the standard technique proposed by Marcos and Carmona 2013 [23].
Chilled larvae (96 \pm 2 -h-old) were removed from food media, washed in water, and sterilized in $5 \%$ bleach and dried. The cuticle from 40 to 60 larvae was then disrupted with two fine forceps. The hemolymph and circulating hemocytes were directly collected in cold PBS solution containing $0.07 \%$ PTU and separated in a $1.5 \mathrm{~mL}$ microcentrifuge tube. Pooled hemolymph was centrifuged at $\times 300 \mathrm{~g}$ for $10 \mathrm{~min}$ at $4^{\circ} \mathrm{C}$; the supernatant was discarded and the pellet was resuspended in $20 \mu \mathrm{L}$ of cold PBS.

The comet assay was performed as previously described by Singh et al. 1988 [26] with slight changes. Cell samples $(\sim 40,000$ cells in $20 \mu \mathrm{L})$ were carefully resuspended in $140 \mu \mathrm{L}$ of $0.75 \%$ LMA, layered onto microscope slides pre-coated with $150 \mu \mathrm{L}$ of $1 \%$ NMA (dried at room temperature). Two gels were mounted on each slide and covered with a coverslip. Immediately after agarose solidification $\left(10 \mathrm{~min}\right.$ at $\left.4^{\circ} \mathrm{C}\right)$, the coverslips were removed and the slides were immersed in cold, freshly made lysis solution $(2.5 \mathrm{M} \mathrm{NaCl}, 100 \mathrm{mM} \mathrm{Na}$ EDTA, $10 \mathrm{mM}$ Tris, $1 \%$ Triton $\mathrm{X}-100$, and $1 \% \mathrm{~N}$-lauroylsarcosine, $\mathrm{pH} 10$ ) for $2 \mathrm{~h}$ at $4^{\circ} \mathrm{C}$ in a dark chamber. DMSO was omitted from the lysis solution because it has been considered unnecessary for Drosophila tissues, and DMSO at low concentrations is cytotoxic in Drosophila [15]. To avoid additional DNA damage, the next steps were performed under dim light. Slides were placed for $25 \mathrm{~min}$ in a horizontal gel-electrophoresis tank filled with cold electrophoresis buffer $(1 \mathrm{mM}$ Na2EDTA, $300 \mathrm{mM} \mathrm{NaOH}$, $\mathrm{pH} 13$ ) to allow DNA unwinding. Electrophoresis was carried out in the same buffer for $20 \mathrm{~min}$ at $25 \mathrm{~V}$ and $300 \mathrm{~mA}$. The unwinding and electrophoresis were done at $4^{\circ} \mathrm{C}$. After electrophoresis, slides were neutralized with two washes of $5 \mathrm{~min}$ with $0.4 \mathrm{mM}$ Tris ( $\mathrm{pH}$ 7.5). The slides were stained with $20 \mu \mathrm{L}$ of DAPI $(1 \mu \mathrm{g} / \mathrm{mL})$ per gel. The images were examined at $400 \times$ with a Komet 5.5 Image-Analysis System (Kinetic Imaging Ltd., Liverpool, UK) fitted with an Olympus BX50 fluorescence microscope equipped with a 480-550-nm wide-band excitation filter and a 590 -nm barrier filter. One hundred and fifty cells were examined ( 25 cells/slide from two slides per experimental group, three experiments per group). The percentage of DNA in the tail (\%DNA tail) was used to measure DNA damage, because this is the most widely used and recommended parameter for comet-data analysis $[27,28]$.

\section{Warts-based SMART assay}

To obtain wts/+heterozygote larvae, virgin females carrying one copy of the mutant tumor suppressor allele and a balancer chromosome (TM3, $S b^{1}$ ) were crossed with wild-type (Oregon $\mathrm{R}^{+}$) males as previously described by Eeken et al. 2002 [21]. The eggs of the descendants were collected during an $8 \mathrm{~h}$ period. After $72 \pm 4 \mathrm{~h}$, the third-instar larvae were washed in reverse osmosis water and collected using a fine mesh sieve. The larvae from this cross were treated with NGT. The larvae were placed in glass flasks containing standard Drosophila food and different concentrations of NGT and were allowed to grow on it. The larvae were submitted to a chronic treatment for approximately $48 \mathrm{~h}$. However, only adult flies, without the chromosome balancer (TM3, $S b^{1}$ ) were analyzed for tumor clones and they did not have truncated bristles. Scoring of wts was conducted according to Abou-Eisha et al. 2016 [14].

\section{Statistical analysis}

The conditional binomial test according to Kastenbaum and Bowman 1970 [29] was applied to assess differences between the frequencies of each type of spot in treated and concurrent negative control flies with $5 \%$ significance levels. For evaluation of the induced effects, the multiple-decision procedure described by Frei and Würgler 1988 [30] was used to judge the overall response of an agent as positive, weakly positive, negative, or inconclusive. Differences in the percentage of DNA damage in the tail of different treatment groups were compared with those of the control, using the general linear model (GLM). The GLM approach is analogous to the traditional ANOVA, but it allows the use of non-normal data, which is our case [15]. Before analysis with GLM, the homogeneity of variance and normality assumption of data was tested with the Bartlett and Kolmogorov-Smirnov tests, 
respectively. For multiple comparisons between groups, the Tukey's HSD test was carried out. On the other hand, the statistical significance of the differences between tumor frequencies in the treatment and control was calculated using the non-parametric Mann-Whitney U-test. Statistical significance was set at $p \leq 0.05$. Data analyses were performed using SAS program (v9.3, SAS Institute Inc., Cary, NC, USA)

\section{RESULTS}

The different clinical concentrations utilized in experiments to examine the genotoxicity and tumorigenic potentials were appropriate for larval viability. The viability of larvae was more than $70 \%$ at concentrations ranged from $0.24 \mu \mathrm{M}$ to $1.6 \mu \mathrm{M}$ except for the highest concentration $16 \mu \mathrm{M}$, viability was lessening, but it was sufficient to perform these experiments where viability was higher than $50 \%$. Elevated toxicity observed at the highest concentration $16 \mu \mathrm{M}$ shown in both a lessened proportion of larvae developing into grown-ups and a lateness within the time wanted for the larvae to progress into the grown-up stage.

The data obtained from the experiment assigned to examine the genotoxicity of NGT in the wing-spot assay are shown in Table 1 . The attained results revealed that NGT did not produce a significant increase at all tested concentrations in the frequency of the three mutant spots (small single, large single, and twin spots) in comparison with negative control. On the contrary, the results obtained with MMC showed a positive response, which supports the accurate performance of this method, and the validity of the negative data found with this hormonal drug examined in this assay.

In the same vein, the results observed in the comet test after treatment of larvae of D. melanogaster with four concentrations of NGT to test the genotoxicity are shown in Fig. 1. NGT was given to the larvae (72 \pm 4 -h-old) for $(24 \pm 2 \mathrm{~h})$ at doses ranging from $0.24 \mu \mathrm{M}$ to $16 \mu \mathrm{M}$. The results indicated that none of the tested doses induced a significant increment of DNA damage represented as the percentage of DNA in the tail on Drosophila hemocytes when compared with the negative control. On the other hand, the positive control with $50 \mu \mathrm{M}$ of MMC demonstrated a sharp increment of DNA damage on hemocytes, which strengthen the acceptability of the negative results determined during this work. In summary, our in vivo genotoxicity data with this synthetic progestin indicate that it is not genotoxic with these assays (wing spot test and comet assay), at least under the experimental conditions applied.

NGT was tested for its ability to cause tumors by applying the $w t s$-based SMART method on D. melanogaster. This precise method used in the fruit fly gives a clear picture of whether a substance has the capability of inducing cancer-causing risk to humans or not. The results revealed that there was no significant difference among the tumor frequencies found at all examined concentrations of NGT and the negative control. Thus, suggesting an absence of the oncogenic potential of this hormonal drug (Table 2). Nevertheless, the frequencies of tumor induction exhibited a highly significant increase after feeding the Drosophila larvae with MMC treatment, thus confirming the validity of wts-based SMART experiment and the results obtained.

\section{DISCUSSION}

In the present study, to increase our information about the possible genotoxic hazard correlated with NGT, we employed two recognized in vivo methods to assess the genotoxicity of NGT in somatic cells of Drosophila. On the single hand, the wing-spot test is a method depending on the loss of heterozygosity production that might take place through several ways, such as a wide range of mutational events as well as mitotic recombination. This outstanding technique detects concurrently mutational and mitotic recombination, being able to enumerate the recombinogenic activity of a substance in a genotoxicity screening [31]. In the same vein, the comet experiment is an outstanding technique broadly utilized for in vivo mutagenicity screening, since it can employ to a varied variety of cells, it can detect lesser amounts of DNA impairment and can identify various kinds of DNA damage [32]. Hence, this assay is being frequently used effectively to measure DNA damage in different cells and model organisms, including D. melanogaster [33]. On the other hand, NGT examined for carcinogenic activity by applying the wts-based SMART technique on D. melanogaster as transgenic model organisms. This method is one of the famous SMART analysis in Drosophila, where any mutation that results in a lack of function of wts gene might cause a noticeable phenotypes changes in the eyes and wings of the fly. This test is based

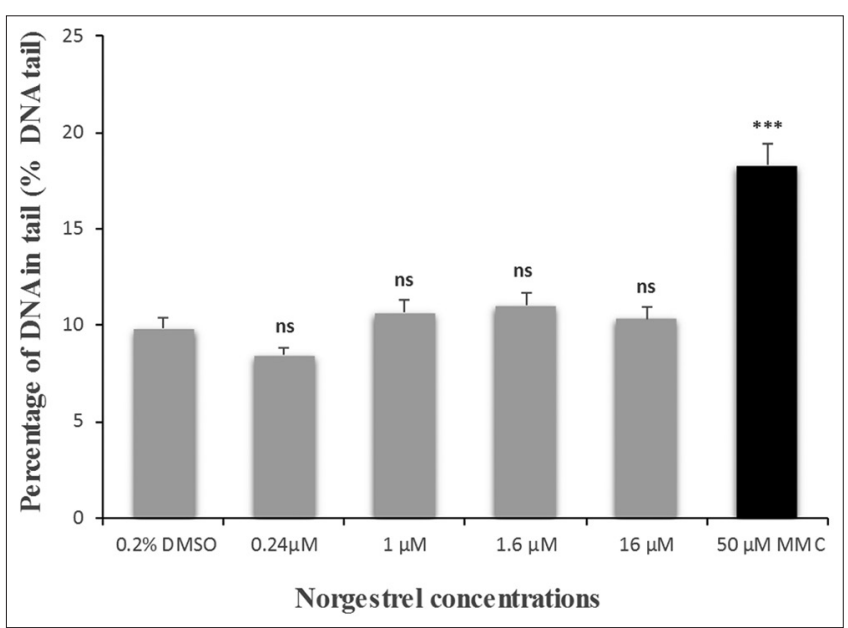

Fig. 1: Primary DNA damage measured by the in vivo comet assay in hemocytes from Drosophila melanogaster larvae treated with norgestrel. Dimethyl sulfoxide $0.2 \%$ was used as negative control and mitomycin $\mathrm{C}$ as positive control. ${ }^{* * *} \mathrm{p}<0.001, \mathrm{~ns}$ : No significant against negative control

Table 1: Induction of wing spot in Drosophila after larval treatment with NGT

\begin{tabular}{|c|c|c|c|c|c|c|c|c|c|c|c|c|c|}
\hline \multirow[t]{2}{*}{ Compound concentration $(\mu \mathrm{M})$} & \multirow[t]{2}{*}{ Number of wings scored } & \multicolumn{3}{|c|}{$\begin{array}{l}\text { Small single } \\
\text { spots }(1-2 \\
\text { cells })(m=2)\end{array}$} & \multicolumn{3}{|c|}{$\begin{array}{l}\text { Large single } \\
\text { spots }(>2 \\
\text { cells })(m=5)\end{array}$} & \multicolumn{3}{|c|}{$\begin{array}{l}\text { Twin } \\
\text { spots }(m=5)\end{array}$} & \multicolumn{3}{|c|}{$\begin{array}{l}\text { Total } \\
\text { spots }(m=2)\end{array}$} \\
\hline & & $\mathbf{N}$ & $\mathrm{Fr}$ & D & $\mathbf{N}$ & $\mathbf{F r}$ & D & $\mathbf{N}$ & Fr & D & $\mathbf{N}$ & $\mathrm{Fr}$ & D \\
\hline Control & 80 & 22 & 0.28 & & 1 & 0.01 & & 0 & 0.00 & & 23 & 0.29 & \\
\hline DMSO $0.2 \%$ & 80 & 24 & 0.30 & - & 2 & 0.03 & $\mathrm{i}$ & 0 & 0.00 & $\mathrm{i}$ & 26 & 0.33 & - \\
\hline \multicolumn{14}{|l|}{ NGT } \\
\hline 1 & 80 & 16 & 0.20 & - & 3 & 0.04 & $\mathrm{i}$ & 0 & 0.00 & $\mathrm{i}$ & 19 & 0.24 & - \\
\hline 1.6 & 80 & 19 & 0.24 & - & 2 & 0.03 & $\mathrm{i}$ & 0 & 0.00 & $\mathrm{i}$ & 21 & 0.26 & - \\
\hline 16 & 80 & 21 & 0.26 & - & 2 & 0.03 & $\mathrm{i}$ & 0 & 0.00 & $\mathrm{i}$ & 23 & 0.29 & - \\
\hline \multicolumn{14}{|l|}{ MMC } \\
\hline 50 & 80 & 60 & 0.75 & + & 31 & 0.39 & + & 15 & 0.19 & + & 106 & 1.33 & + \\
\hline
\end{tabular}

N: Number, Fr: Frequency, D: Statistical diagnosis according to Frei and Würgler (1988), +: Positive, -: Negative, i: Inconclusive, $m$ : Multiplication factor, levels of probability $\alpha=0.05$. DMSO: Dimethyl sulfoxide; MMC: Mitomycin C, NGT: Norgestrel 
Table 2: Frequency of tumor clones observed in heterozygous offspring of D. melanogaster after treatment with NGT

\begin{tabular}{|c|c|c|c|c|c|c|c|c|c|}
\hline \multirow[t]{2}{*}{ Treatment concentration $(\mu \mathrm{M})$} & \multirow[t]{2}{*}{ Total flies scored } & \multicolumn{7}{|c|}{ No. of tumors scored } & \multirow{2}{*}{$\begin{array}{l}\text { Frequency (No. of } \\
\text { tumors/fly) }\end{array}$} \\
\hline & & Eyes & Head & Wing & Body & Leg & Halter & Total & \\
\hline Control & 200 & 1 & 0 & 11 & 7 & 4 & 0 & 23 & 0.115 \\
\hline DMSO $0.2 \%$ & 200 & 0 & 4 & 6 & 9 & 3 & 0 & 22 & 0.110 \\
\hline \multicolumn{10}{|l|}{ NGT } \\
\hline 0.24 & 200 & 0 & 0 & 4 & 8 & 3 & 1 & 16 & 0.080 \\
\hline 1 & 200 & 1 & 2 & 5 & 8 & 2 & 0 & 18 & 0.090 \\
\hline 1.6 & 200 & 3 & 1 & 3 & 9 & 3 & 0 & 19 & 0.095 \\
\hline 16 & 200 & 3 & 2 & 3 & 8 & 4 & 0 & 20 & 0.100 \\
\hline \multicolumn{10}{|l|}{ MMC } \\
\hline 50 & 200 & 83 & 39 & 114 & 123 & 59 & 12 & 430 & $2.15^{* *}$ \\
\hline
\end{tabular}

Analysis of tumor frequency data is identified by the Mann-Whitney U-test. Levels of probability indicated as *p<0.05, ${ }^{* *} \mathrm{p}<0.01$, and ${ }^{* * *} \mathrm{p}<0.001$ comparing with negative control. DMSO: Dimethyl sulfoxide, MMC: Mitomycin C, NGT: Norgestrel, D. melanogaster: Drosophila melanogaster

on the wts gene, which is straightforwardly included in control of the cell cycle and its analogous are tumor suppressor genes present in some lower organisms in addition to mice and human [18]. Exposure of $w t s$ heterozygous individuals in larval stage to carcinogenic or mutagenic factors leads to loss of heterozygosity in some epithelial cells, which causes to induce tumors that could be recorded in adult insects [21]. Furthermore, the authors [18,21] reported that this technique displayed high sensitivity to a broad spectrum of mutagenic and carcinogenic compounds.

In this research work, no genotoxic effects of the synthetic progestin NGT have been detected in the D. melanogaster SMART wing-spot test (Table 1) as well as the comet assay (Fig. 1). In agreement with our results, treatment of the Syrian hamster embryo cells that do not have any measurable levels of the nuclear androgenic receptor with NGT or diethylstilbestrol failed to induce DNA damage, chromosome abnormalities, and gene mutations [34]. In addition, the synthetic progestin levonorgestrel did not increase point mutations in the Ames Salmonella/microsome test with or without a metabolic activation system [35]. In addition, the same author obtained negative results in chromosomal aberration test in an in vitro Chinese hamster ovary cells and an in vivo micronucleus assay in mice. In the same sense, several authors recorded negative results in the comet test on different types of human cell lines treated with oral contraceptive drugs [36,37]. However, Ahmad et al. 2001 [6] reported that NGT-induced sister chromatid exchanges and chromosomal abnormalities in human lymphocytes in vitro and significantly increase mitotic index with and without metabolic activation system. In the same regard, Siddique et al. 2006 [13] also observed the same finding but only in the presence of a metabolic activation medium.

On the other hand, our results showed that there was no significant difference ( $p>0.05$ ) among the tumor frequencies found at all examined doses of NGT and the negative control in the wts-based SMART assay, thus suggesting an absence of cancer-causing action of NGT (Table 2). In agreement with this finding, Backman et al. 2005 [38] reported that Finnish female users of the synthetic progestin levonorgestrel did not show an increase in the incidence of breast cancer when compared with the average. Moreover, the steroidal drug $17 \beta$-estradiol was found to be nongenotoxic at all tested concentrations and failed to increase the frequency of tumors in the somatic cells of D. melanogaster [14]. However, NGT significantly upraised the protein expression of CD44, an important cancer stem cell marker in tumor cells [6]. In the same context, Kresowik et al. 2008 [39] found that levonorgestrel led to increasing endometrial thickness during the usage of the levonorgestrel-releasing intrauterine system. Like all the synthetic progestins, NGT has an affinity for binding to the progesterone receptors [40]. Similar to progesterone hormone, NGT, when binding with progesterone receptors stimulates gene transcription as well as influencing cell proliferation and differentiation in target tissues [41]. In this regard, NGT stimulates MCF-7 breast cancer cell growth by activating the estrogen receptor [42]. Further, NGT was found to increase significantly the frequency of tumor growth and metastasis of BT-474 human breast cancer cells implanted in nude mice [43]. In the same sense, the previous authors found that NGT stimulates expression of vascular endothelial growth factor and CD34 expression in BT-474 xenograft tumors suggesting that it promotes tumor vascularization.

The absence of genetic toxicity in the current study can be attributed to the approved powerful antioxidant effect of NGT, where it prevents the production of reactive oxygen species in the cells [4]. In this context, reactive oxygen species can change the structure of DNA forming mutagenic injuries or producing chromosomal abnormalities, which can cause mutations and induce cancer [14]. NGT acts as an antioxidant agent through modulating the nuclear factor erythroid 2-related factor 2 (Nrf2) [4]. In this regard, Nrf2 works as a cytoprotective factor controlling the expression of the genes responsible for the production of antioxidants, anti-inflammatory, and detoxifying proteins $[4,44]$. Further, the mammalian Nrf2 falls under the category Cap " $n$ " Collar (Cnc) bZIP family of transcription factors and has a high degree of compatibility with the transcription factor $\mathrm{CncC}$ present in D. melanogaster [44].

Moreover, obtained negative results may also be explained by the high efficacy of the biotransformation mechanisms for toxins in Drosophila. Biotransformation of quinones and xenobiotic substances takes place through glutathione conjugation reaction $[45,46]$ in which that reaction mostly includes glutathioneS-transferase that shows an essential job in the formation of glutathione conjugates of catechol estrogen quinones [47]. In this regard, several authors $[48,49]$ demonstrated that glutathione plays a crucial task in diminishing the harmful effects of catechol estrogen quinones. In addition, in D. melanogaster, glutathione-S-transferase does the same role of glutathione peroxidase enzyme to carry out the protection against oxygen-mediated damage probably because of the absence of peroxidase enzyme in Drosophila [50]. It is worth to be mentioned that different stages in the life cycle of a Drosophila have a considerable quantity of the glutathione-S-transferase enzyme [51]. Furthermore, the same authors reported that larval stage showed the most elevated particular action of glutathioneS-transferase. In view of this point, it appears to be sensible to consider that the great amount of glutathione-S-transferase in larval stage might encourage the detoxifying mechanism of NGT metabolites and the produced reactive oxygen species. This would result in both the absence of genotoxicity and tumor frequencies in D. melanogaster.

\section{CONCLUSION}

The data recorded in this investigation revealed that synthetic progestin NGT is not able to induce both genotoxic and carcinogenic effects in somatic cells of $D$. melanogaster. Our results strengthen 
the hypothesis that steroid drugs might act through a non-genotoxic carcinogen mechanism where the carcinogenic properties occur by direct stimulation of cellular proliferation through a steroid receptormediated mechanism. Eventually, these negative results could emphasize recently reported observations that found NGT drug as a potent neuroprotective antioxidant agent.

\section{CONFLICTS OF INTEREST}

The authors declare that there are no conflicts of interest.

\section{AUTHORS CONTRIBUTION}

All authors contributed equally in all parts of this study.

\section{REFERENCES}

1. Siddique YH, Ara G, Beg T, Afzal M. Additive action of vitamin C and E against norgestrel induced genotoxicity. Biomed Res 2007;18:155-60.

2. Hebbar S. Epilepsy and oral hormonal contraception-Indian perspective. Int J Pharm Pharm Sci 2017;9:1-6.

3. Doonan F, O'Driscoll C, Kenna P, Cotter TG. Enhancing survival of photoreceptor cells in vivo using the synthetic progestin Norgestrel. J Neurochem 2011;118:915-27.

4. Byrne AM, Ruiz-Lopez AM, Roche SL, Moloney JN, WyseJackson AC, Cotter TG. The synthetic progestin norgestrel modulates Nrf2 signalling and acts as an antioxidant in a model of retinal degeneration. Redox Biol 2016;10:128-39.

5. Jackson AC, Cotter TG. The synthetic progesterone norgestrel is neuroprotective in stressed photoreceptor-like cells and retinal explants, mediating its effects via basic fibroblast growth factor, protein kinase A and glycogen synthase kinase 3beta signalling. Eur J Neurosci 2016;43:899-911.

6. Ahmad ME, Shadab GG, Azfer MA, Afzal M. Evaluation of genotoxic potential of synthetic progestins-norethindrone and norgestrel in human lymphocytes in vitro. Mutat Res 2001;494:13-20.

7. Siddique $\mathrm{YH}, \mathrm{Beg} \mathrm{T}$, Afzal M. Anticlastogenic effects of ascorbic acid against the genotoxic damage induced by norethynodrel. Adv Environ Biol 2007;1:27-32

8. Goyette S, Liang Y, Mafuvadze B, Cook MT, Munir M, Hyder SM, et al. Natural and synthetic progestins enrich cancer stem cell-like cells in hormone-responsive human breast cancer cell populations in vitro. Breast Cancer (Dove Med Press) 2017;9:347-57.

9. Willibald M, Bayer G, Stahlhut V, Poschmann G, Stühler K, Gierke B, et al. progesterone receptor membrane component 1 is phosphorylated upon progestin treatment in breast cancer cells. Oncotarget 2017:8:72480-93.

10. Siddique YH, Afzal M. Evaluation of genotoxic potential of synthetic progestin chlormadinone acetate. Toxicol Lett 2004;153:221-5.

11. Siddique YH, Ara G, Beg T, Afzal M. Genotoxic potential of medroxyprogesterone acetate in cultured human peripheral blood lymphocytes. Life Sci 2006;80:212-8.

12. Siddique Y, Afzal M. A review on the genotoxic effects of some synthetic progestins. Int J Pharmacol 2008;4:410-30.

13. Siddique YH, Beg T, Afzal M. Protective effect of nordihydroguaiaretic acid (NDGA) against norgestrel induced genotoxic damage. Toxicol In Vitro 2006;20:227-33.

14. Abou-Eisha A, El-Din AE, Darwish HR. Assessment of mutagenic activity of 17B-estradiol in Drosophila melanogaster. Fresen Environ Bull 2016;25:1729-36.

15. Carmona ER, Guecheva TN, Creus A, Marcos R. Proposal of an in vivo comet assay using haemocytes of Drosophila melanogaster. Environ Mol Mutagen 2011;52:165-9.

16. Vidal M, Cagan RL. Drosophila models for cancer research. Curr Opin Genet Dev 2006;16:10-6.

17. Bonneton F, Laudet V. Evolution of nuclear receptors in insects. In: Gilbert LI, editor. Insect Endocrinology. $1^{\text {st }}$ ed. San Diego: Academic Press; 2012. p. 219-52

18. Sidorov RA, Ugnivenko EG, Khovanova EM, Belitsky GA. Induction of tumor clones in D. melanogaster wts/+ heterozygotes with chemical carcinogens. Mutat Res 2001;498:181-91.

19. Nazir A, Mukhopadhyay I, Saxena DK, Chowdhuri DK. Evaluation of the no observed adverse effect level of solvent dimethyl sulfoxide in Drosophila melanogaster. Toxicol Mech Methods 2003;13:147-52.

20. Tsuda H, Takeda N. Effect of tumor promoter TPA on spontaneous and mitomycin $\mathrm{C}$ induced mitotic recombination in Drosophila melanogaster. Mutat Res 1987;189:375-9.

21. Eeken JC, Klink I, van Veen BL, Pastink A, Ferro W. Induction of epithelial tumors in Drosophila melanogaster heterozygous for the tumor suppressor gene wts. Environ Mol Mutagen 2002;40:277-82

22. Dhanraj V, Manivasagam T, Karuppaiah J. Myricetin isolated from turbinaria ornata ameliorates rotenone induced parkinsonism in Drosophila melanogaster. Int J Pharm Pharm Sci 2017;9:39-44.

23. Marcos R, Carmona ER. The wing-spot and the comet tests as useful assays detecting genotoxicity in Drosophila. In: Dhawan A, Bajpayee M, editors. Genotoxicity Assessment: Methods and Protocol. Vol. 1044. New York: Humana Press; 2013. p. 417-27.

24. Graf U, Würgler F, Katz A, Frei H, Juon H, Hall C, et al. Somatic mutation and recombination test in Drosophila melanogaster. Environ Mol Mutagen 1984;6:153-88.

25. Demir E, Kocaoğlu S, Kaya B. Antigenotoxic properties of chlorophyllin and chlorophylls in the Drosophila wing spot test. Fresen Environ Bull 2010;19:3131-8

26. Singh NP, McCoy MT, Tice RR, Schneider EL. A simple technique for quantitation of low levels of DNA damage in individual cells. Exp Cell Res 1988;175:184-91.

27. Kumaravel TS, Jha AN. Reliable comet assay measurements for detecting DNA damage induced by ionising radiation and chemicals. Mutat Res 2006;605:7-16.

28. Lovell DP, Omori T. Statistical issues in the use of the comet assay. Mutagenesis 2008;23:171-82.

29. Kastenbaum MA, Bowman KO. Tables for determining the statistical significance of mutation frequencies. Mutat Res 1970;9:527-49.

30. Frei H, Würgler FE. Statistical methods to decide whether mutagenicity test data from Drosophila assays indicate a positive, negative, or inconclusive result. Mutat Res 1988;203:297-308.

31. Franchi LP, Guimarães NN, De Andrade LR, De Andrade $\mathrm{HH}$, Lehmann M, Dihl RR, et al. Antimutagenic and antirecombinagenic activities of noni fruit juice in somatic cells of Drosophila melanogaster. An Acad Bras Cienc 2013;85:585-94.

32. Hartmann A, Schumacher M, Plappert-Helbig U, Lowe P, Suter W, Mueller L, et al. Use of the alkaline in vivo comet assay for mechanistic genotoxicity investigations. Mutagenesis 2004;19:51-9.

33. Dhawan A, Bajpayee M, Parmar D. Comet assay: A reliable tool for the assessment of DNA damage in different models. Cell Biol Toxicol 2009;25:5-32

34. Tsutsui T, Barrett JC. Neoplastic transformation of cultured mammalian cells by estrogens and estrogen like chemicals. Environ Health Perspect 1997;105 Suppl 3:619-24.

35. Jordan A. Toxicology of progestogens of implantable contraceptives for women. Contraception 2002;65:3-8

36. Bajpayee M, Pandey AK, Parmar D, Mathur N, Seth PK, Dhawan A. Comet assay responses in human lymphocytes are not influenced by the menstrual cycle: A study in healthy Indian females. Mutat Res 2005;565:163-72.

37. Braz MG, Fávero Salvadori DM. Influence of endogenous and synthetic female sex hormones on human blood cells in vitro studied with comet assay. Toxicol In Vitro 2007;21:972-6.

38. Backman T, Rauramo I, Jaakkola K, Inki P, Vaahtera K, Launonen A, et al. Use of the levonorgestrel-releasing intrauterine system and breast cancer. Obst Gynecol 2005;106:813-7.

39. Kresowik J, Ryan GL, Van Voorhis BJ. Progression of atypical endometrial hyperplasia to adenocarcinoma despite intrauterine progesterone treatment with the levonorgestrel-releasing intrauterine system. Obstet Gynecol 2008;111:547-9.

40. Runnalls TJ, Beresford N, Losty E, Scott AP, Sumpter JP. Several synthetic progestins with different potencies adversely affect reproduction of fish. Environ Sci Technol 2013;47:2077-84

41. Graham JD, Clarke CL. Physiological action of progesterone in target tissues. Endocr Rev 1997:18:502-19.

42. Catherino WH, Jeng MH, Jordan VC. Norgestrel and gestodene stimulate breast cancer cell growth through an oestrogen receptor mediated mechanism. Br J Cancer 1993;67:945-52.

43. Liang Y, Benakanakere I, Besch-Williford C, Hyder RS, Ellersieck MR, Hyder SM, et al. Synthetic progestins induce growth and metastasis of BT-474 human breast cancer xenografts in nude mice. Menopause 2010;17:1040-7

44. Loboda A, Damulewicz M, Pyza E, Jozkowicz A, Dulak J. Role of nrf2/HO-1 system in development, oxidative stress response and diseases: An evolutionarily conserved mechanism. Cell Mol Life Sci 2016:73:3221-47.

45. Reed DJ. Glutathione: Toxicological implications. Annu Rev Pharmacol Toxicol 1990;30:603-31. 
46. Chandrasena RE, Edirisinghe PD, Bolton JL, Thatcher GR. Problematic detoxification of estrogen quinones by $\mathrm{NAD}(\mathrm{P}) \mathrm{H}$-dependent quinone oxidoreductase and glutathione-S-transferase. Chem Res Toxicol 2008;21:1324-9.

47. Raftogianis R, Creveling C, Weinshilboum R, Weisz J. Estrogen metabolism by conjugation. JNCI Monographs 2000;2000:113-24.

48. Cavalieri E, Frenkel K, Liehr JG, Rogan E, Roy D. Chapter 4: Estrogens as endogenous genotoxic agents-DNA adducts and mutations. JNCI Monographs 2000;2000:75-94.
49. Zahid M, Saeed M, Ali MF, Rogan EG, Cavalieri EL. N-acetylcysteine blocks formation of cancer-initiating estrogen-DNA adducts in cells. Free Rad Biol Med 2010;49:392-400.

50. Parkes TL, Hilliker AJ, Phillips JP. Genetic and biochemical analysis of glutathione-S-transferase in the oxygen defense system of Drosophila melanogaster. Genome 1993;36:1007-14.50.

51. Hunaiti AA, Elbetieha AM, Obeidat MA, Owais WM. Developmental studies on Drosophila melanogaster glutathione S-transferase and its induction by oxadiazolone. Insect Biochem Mol Biol 1995;25:1115-9. 